\title{
DAĞITIM KANALLARINDA BAYİLERİN ÜRETICİ FİRMA LEHİNE İŞBİRLİĞİ DAVRANIŞLARINI ETKİLEYEN FAKTÖRLERİ İNCELEYEN BİR ARAŞTIRMA
}

\author{
Cengiz YILMAZZ ${ }^{I}$, Ebru Tümer KABADAYI ${ }^{2}$ \\ ${ }^{\prime}$ Gebze İleri Teknoloji Enstitüsü, İ̧letme Fakültesi Üretim ve Pazarlama, Yardımcı Doçent Dr. \\ ${ }^{2}$ Gebze İleri Teknoloji Enstitüsü, İsletme Fakültesi Üretim ve Pazarlama, Araştırma Görevlisi
}

\begin{abstract}
This paper highlights the importance of cooperative behaviors between supplier firms and independent resellers in contractual distribution channels, where each reseller (i.e., dealer) acts as an independent profit center. Three major facets of cooperation (i.e., solidarity, information exchange, and flexibility) are discussed, and two major factors (dependence and trust) are theorized as facilitating cooperative behaviors. Supplier dependence, dealer dependence, and dealer's trust on the supplier are hypothesized as promoting cooperative tendencies of resellers. The retationships hypothesized in the conceptual section of the article are subjected to empirical testing using data obtained from 192 independent dealers in the Turkish automobile industry. Theoretical and managerial implications of the study findings are discussed.
\end{abstract}

\section{GİRIS}

Ürünlerini, çok sayıda bağımsız aracıdan oluşan bayilik sistemleri yoluyla geniş coğrafi bölgelere yayılmış nihai tüketicilere ulaştırmaya çalışan üretici firmaların, dağıtım fonksiyonlarını kaliteli ve etkin bir şekilde gerçekleştirmeleri son derece önemli bir rekabet faktörü olarak ortaya çıkmaktadır. Pazarlama literatüründe son 10 yıla damgasını vuran ilişkisel pazarlama kuramı, bu ve benzeri "ilişki yöntemlerinin" şekillendirilmesi konusunda önemli gelişmeler göstermiştir. Bu kurama göre bayilerin etkin ve gönüllü işbirliğini sağlayan tedarikçi firmalar, yalnızca dağıtım etkinliği ve kalitesi açısından üstünlük sağlamakla kalmayacaklar, aynı zamanda (müşteri memnuniyeti de olumlu etkileneceğinden) uzun vadede rakiplerine göre daha yüksek finansal performans elde edeceklerdir. Ayrıca, işletmelerin pazar paylarını artırmalarında, maliyetlerini düşurmelerinde ve dolayısıyla rakipleri karşısında daha etkin olmalarında bayilerle aralarındaki işbirliği derecesinin yüksek olmasının büyük önemi vardır.

Dağıtım kanalı içerisinde, her görevi üreticinin yerine getirmesi mümkün değildir. Üretici malı ürettikten sonra, dağıtım aşamasında genellikle dağıtıcı kullanma yoluna gitmektedir. $\mathrm{Bu}$ da üyeler arasında karşılıklı bağımlılığı ve dolayısıyla etkin işbirliği gerekliliğini ortaya çıkartmaktadır. Kanal içerisinde dağıtım işlevinin etkin ve ekonomik bir șekilde yerine getirilmesi için üyeler arasında işbirliginin olması temel ve hayati bir husustur [1]. Bu makalede, (1) bağımsız bayilerden oluşan kanal sistemlerinde bayilerin üretici firma lehine işbirliği kapsamındaki davranışlarının önem ve nitelikleri incelenecek ve (2) literatürde bu davranışları etkileyen en önemli faktörler olarak nitelenen bağımlılık ve güven unsurlarının işbirliği davranışlarının çeşitli boyutları üzerindeki görece etkileri Türk otomobil sektöründe gerçekleştirilen bir araştırma ile ortaya konulmaya çalışılacaktır.

\section{DAĞITIM KANALLARINDA IŞBİRLİĞi ve ÖNEMI}

En genel anlamıyla işbirliği, tarafların ortak bir amaca ulaşmak için gönüllü güç birliği oluşturmaları ve birlikte çalışmaları olarak tanımlanmaktadır [2]. Burada önemli olan kavramlar, çoğu zaman finansal etkinlik şeklinde ortaya çıkan "ortak amaç" kavramı ve tarafların karşılıklı gönüllülüğüdür. İşbirliğgi, tarafların birlikte çalışmaları ve imkanlarını birleştirmeleri suretiyle başarıya ulaşmalarında oldukça büyük bir etkiye sahip olabilir [3].

Anlaşılacağı gibi, dağıtım kanallarında kanal üyeleri arasındaki işbirliğinden söz ederken, bu firmaların ortak iş alanları kapsamına giren bütün işlevlerin gerçekleştirilmesi sürecinde gönüllü birliktelikler kastedilmektedir. Kanal üyeleri, gerek fiziksel dağıtım ve lojistik fonksiyonlarını yerine getirirken ve gerekse kredileme, pazar analizleri, ortak tutundurma kampanyaları, teslimat ve ödemelerde esneklik gösterme ve benzeri alanlarda etkin işbirliği anlayışı yaratabilirler. İşbirliği içindeki firmalar birbirlerine daha fazla güven duygusu besler ve önemli(kritik) bilgilerini paylaşırlar. Ayrıca işlerin yürütülmesi sırasında üzerlerine düşen görevleri en iyi şekilde yerine getirirler ve birbirlerini 
daha iyi anlar ve yardımcı olurłar. Böylesi bir işbirliği ortamının gerçekleştirilebilmesi halinde, bütün katılımcıların karlı çıktığı bir örgütsel yapılanma oluşacaktır. Ayrıca, paylaşım ve görev bölüşümünün gerçekleşmesi sayesinde sermaye ve kaynak gerekliliği göreceli olarak azalacak, maliyetleri düşecektir [4]. Böylece, ana/tedarikçi firmalar dağıtım kanallarındaki ortakları ile girdikleri işbirliğini ön plana çıkararak iş ilişkileri sonucunda rakipleri karşısında daha avantajlı duruma gelme şansına sahip olacaklardır.

$\mathrm{Bu}$ çalışmada, literatürde [5] firmalar arası işbirliği davranışlarının sınıflandırılması yapılırken en çok üzerinde durulan üç temel boyut incelenecektir. Çalışmamızın bağımlı değişkenlerini oluşturan söz konusu odak unsurlar, (1) birlik anlayışı, (2) bilginin paylaşımı ve (3) esneklik [6] kapsamındaki işbirliği davranışlarıdır. Aşăğıda tanımlanan bu üç temel işbirliği boyutu, kanal üyelerinin ortak çalışma alanı kapsamına giren bütün alanlarda - başta fiziksel dağttım işlevleri ve ortak pazarlama / tutundurma faaliyetleri olmak üzere karşılıklı anlayışın ve birlikteliğin egemen olduğu yaklaşımları içerir.

- Birlik anlayışl, ilişkinin devamlılı̆̆na yönelik davranışları içeren karşıllkhı bir beklentidir [7]. Birlik anlayışı içindeki firmalar ilişkinin devamını sağlayacak şekilde davranışlar sergilerken, ilişkinin değerini de iyi bilirler; gerektiğinde birbirlerine yardımcı olmaktan ve fedakarlık yapmaktan kaçınmazlar ve her iki tarafin da yararına olacak gelişmelerle ilgilenirler. Birlik anlayıșı beraberlik hissi yaratır ve ortaklar arasındaki "aynı geminin yolcusuyuz" duygusunun bir göstergesidir [8]. Örneğin, böyle bir anlayışın yoğun olduğu bayilik sistemlerinde bayiler, ana firmanın kar marjı yüksek ürünlerini satmak için gösterdikleri özenin aynısını düşük marjlı ürünler için de gösterme eğiliminde olabilirler.

- Bilgi paylaşımı, ortakların birbirinin işine yarayacak kritik bilgileri herhangi bir zorlama olmadan ve tam zamanında birbirleriyle paylaşmalarıdır [9]. Bilgi paylaşımı; kritik, önemli ve özel bilginin kanal ortakları ile ne derece paylaşıldığının bir göstergesi olarak karşımıza çıkmaktadır [10]. Bilgi paylaşımının yeterli olmaması ortaklar arasında birçok problemin doğmasına ve çatışmalara sebep olacaktır. Bu sebeple etkin işbirliğinin sürdürülebilmesi için, gerekli bilginin zamanında ve doğru bir şekilde ortaklarla paylaşılması önemlidir. Örneğin, bayiler müşteri portfôyleri ve gizli satış taktikleri ile ilgili bilgileri ana firma ile paylaşıyorlarsa bilgi paylaşımının yüksekliğinden söz edilebilir.

- Esneklik ise, kanalda yer alan ortakların ilişkide gelecekte meydana gelebilecek (beklenen veya beklenmeyen) değişimlere karșı birbirlerinin gereksinimlerini gözeterek gerekli düzenlemelere gitme istekliliggidir [6] Çevresel belirsizliğin ve hızlı değişmelerin sık rastlandığı günümüz ekonomilerinde, firmaların ortaklarına karşı gerekli durumlarda esnek davranmalarının önemi daha da belirgin hale gelmiştir. Örnek vermek gerekirse, esneklik unsurunun sağlıklı bir şekilde işlediği bayilik sistemlerinde, gerek bayiler ve gerekse ana (üretici) firmalar karşılıklı teslimatlarda ve ödemelerde ortaya çikabilecek geçici aksakllklara daha yapıcı tepkiler verecek, karşı tarafi sıkıştırma, cezalandırma yada hukuki yollara başvurma gibi yöntemlere başvurma eğilimleri çok düşük olacaktrr. Ayrıca, değişen çevre koşulları neticesinde karşı taraftan gelecek özel isteklere olumlu yanıt verme çabası içinde olacaklardır.

Sonuç olarak, tedarikçi firmalar açısından başarılı bayi ilişkileri yönetimi ve bayilerinin gönüllü işbirliğine istekli olmaları önemli bir faktör olarak ortaya çıkmaktadır. Aşağıda, kanal ortaklarının iş̧irliği davranışlarmı etkileyen temel faktörlerden literatürde ön plana çıkan iki önemli unsur olan bağımllık ve güven kavramları üzerinde durulacaktır. Unutmamak gerekir $\mathrm{ki}$, gerçekte işbirliğini etkileyen faktörler bu ikisi ile sınırlı değildir. Taraflar arası kültürel yakınlık derecesi, iş ilişkisinin geleceğine yönelik beklentiler, pazardaki ve diğer çevresel faktörlerdeki belirsizlik düzeyi, taraflar arasınđaki sözleşmelerin içeriği ve benzerleri gibi pek çok faktör işbirliği eğilimlerini etkileyebilmektedir. Araştırmamız, bağımlılık ve güven faktörleri üzerinde durarak ve bunların işbirliğinin çeşitli unsurları üzerine görece etkilerini inceleyerek bu konudaki mevcut bilgi birikimine sinılı - fakat yeterince anlaml - bir katkıda bulunmayı hedeflemektedir.

\section{IŞBBIRLIĞİINI ETKİLEYEN TEMEL FAKTÖRLERDEN BAĞIMLILIK ve GÜVEN}

\section{A. Bağımlılık}

Bağımlılık, bir üyenin amaçlarma ulaşmak için ortağı ile olan ilişkisini devam ettirme ihtiyacı olarak tanımlanabilir [11]. Genel olarak kanal üyeleri, karșilıklı çıarları devam ettiği sürece birbirleri ile olan ilişkilerini devam ettirme intiyaci ve çabası içerisinde olacaklardır.

Bir firmanın bağımlı olmasının birçok anlamı vardır. Emerson'a (1962) göre, bir firmanın ortak iş yaptığı başka bir firmaya olan bağımlılığı başlıca iki temel faktör tarafindan belirlenmektedir. Bunlardan birincisi, iș ilişkisi sayesinde karşı taraftan elde edilen toplam ekonomik değer (ekonomik önem) ile ölçülmektedir. Başka bir deyişle, ortaklardan biri diğerinin kendisinin gelecekteki ve mevcut performansı, iş başarısı v.b için önemli olduğunu "düşünüyorsa, bağımlılık derecesi de 0 ölçüde fazlalaşacaktı̣r. Bağımlılığın ikinci temel unsuru, mevcut kanal ortağından elde edilen ekonomik değerin alternatiflerle 
ikame edilebilme zorluğu (yerine konulabilirlik) olarak ifade edilmektedir. Eger her iki taraf için de alternatifler mevcut değilse karşılıklı bağımlılık derecesi yüksek olacaktır. Diğer taraftan, kanal ilişkileri konusunda çalışmalar yapan araştırmacılar, bağımlılık derecesini belirleyecek üçüncü bir unsur olarak, belirli bir iş ilişkisine özgün olarak gerçekleştirilen yatırımların (özgün yatırımlar) miktarının da önemli olabileceğini ortaya koymuşlardır [9]. Özgün yatırmmlar, mevcut iş ilişkisini desteklemek için gerekli olan, ilişkiye özel fiziksel ve beşeri varlıklardır. Eğer ilişki sona erecek olursa, bu yatırımların ilişkiye özel olmalarından dolayı başka alanlarda kullanılması mümkün olmayacak ve bu da ayrılma maliyetini ortaya çıkartacaktır. Ayrılma maliyetinin yüksek olması tarafların birbirlerine karşı olan bağımlılık derecelerini artıracaktır. Sonuç olarak, bu üç unsurun da (özgün yatırımlar, önem ve yerine konulabilirlik) tarafların birbirlerine karşı olan bağımlılık seviyeleri üzerinde önemli etkileri vardır.

Diğer taraftan, güç ile bağımlılık arasında da yakın bir ilişki vardır $[12,13]$. Gücü, bir kanal üyesinin diğer kanal üyesinin davranış ve karar değişkenlerini etkileme yeteneği olarak tanımlamamız mümkündür [14]. Güç, taraflardan birinin kritik kaynaklara sahip olması ve alternatif kaynakların kontrolünü elinde bulundurması ile ortaya çıkmaktadır [15]. Bir firma başka bir firmaya ne derece bağımlı ise, karşı tarafa o derece "gücü" devretmiş olacaktır. Kısaca daha az bağımlı olan taraf daha fazla bağımlı olan tarafa göre daha güçlü durumda olacaktır. Örneğin, çoğu bayilik sistemi içerisinde, bayilerin bağımlılık derecesi, birlikte çalıştığı ana firmanın bağımlılığına göre daha fazladır ve dolayısıyla üretici (ana firma) daha güçlü durumdadır.

İki ortağın karşılıklı bağımlılık seviyeleri arasında farkın olup olmaması, bağımlılık simetrisi ya da asimetrisi kavramını ortaya çkartmaktadır. Eger bir kanal ilişkisinde her iki taraf ta birbirine bağımlı durumda ise, firmalar arasındaki karşılıklı bağımlılık (üretici ve bayi bağımlılığı) yüksektir ve simetriktir. Böyle durumlarda her bir firma yüksek derecede güce sahiptir ve firmalar arasındaki bağların çok güçlü olması gerekir. Bu gibi ilişkiler zayıf ya da işlevsel olmayan ilişkiler değildir, tam tersidir. Ortak gücün yüksek olması nedeniyle, böyle bir kanal ilişkisi içerisinde mevcut olan ortak çıarlar, karşılıklı güven, bağlılık ve işbirliğini artırır $[5,11,16]$.

Diğer taraftan, bir firmanın bağımlılık derecesi yüksek iken diğerinin daha düşük olması bağımlılık asimetrisini ortaya çıkartmaktadır. Bağımlılık asimetrisi, üretici firmanın bağımlılı̆̆ı ile bayi bağımlılığı arasındaki farktır. [8,13,17]. Bağımlllıkta asimetri söz konusu ise, çıkarların farklılık arz ettiği durumlarda düşük bağımlıliktan kaynaklanan güç avantajına sahip firma bencil davranabilir ve diğer firmayı baskı altına alabilir [18-20]. Ayrıca, kanalın gittikçe asimetrik hale gelmesi, kanal üyelerini birbirinden uzaklaştiracaktır. Daha güçlü ve daha az bağımlı olan tarafin, ortağı ile güven ve bağlılığa dayalı bir dostluk kurmasına ihtiyacı yoktur; çünkiu gücünü kullanmak suretiyle ortağının kendisine itaat etmesini sağlamaktadır. Daha güçlü olan tarafin işbirliğine ve güven duyulmaya daha az ihtiyacı vardır [19]. Ancak kısa vade de güçlü firma birçok avantajlar elde ediyor gibi gözükse de, uzun vade de sistemin başarısı ve devamlılığı açısından birçok olumsuzluklar ortaya çıkmakta, dağıtım sistemi etkinliğini kaybetmekte ve taraflar başarısız olmaktadır [21].

Ayrıca, karşılıklı kanal ilişkisindeki her bir firma düşük seviyeli bir bağımlılığa sahip ise, karşılıklı bağımlılık düşüktür ve her bir firmanın gücü azdır. Karşılıklı bağımlılığın düşük olmasından dolayı bağımlılık düzeylerinin simetrik oluşu da önemini yitirir. Böyle bir durumda her bir firmanın diğerine karşı olan dikkat ve destek eğilimi de çok azalır. Eğer furmalardan biri gerçekçi olmayan taleplerde bulunmaya başlarsa, ilişkiler işlevselliğini yitirir. Bunun sebebi taraflar arasındaki karşılıklı bağımlılığn düşük olmasıdır [22].

\section{B. Güven}

Moorman, Deshpande ve Zaltman [25] iki firma arasındaki güveni; tarafların birbirlerinin dürüstlügüne, doğruluğuna, ticari ahlakına v.s. ve dolayısıyla bilerek birbirlerine zarar vermeyeceklerine ilişkin olan inançlarından gelen risk alma eğilimi olarak tanımlamışlardır. Tarafların ilişkilerindeki karşılıklı risk alma eğilimi güven unsurunun doğal bir sonucudur [21]. Güven, bir ilişkinin temelini oluşturan direkler gibidir. İtimat(credibility) ve iyi niyet(benevolence) güvenin gerektirdiği şartlardandır. İtimat, iş ilişkilerini etkin bir şekilde yürütebilmek için ticari ortağın, doğrucu ve dürüst olduğuna dair inançtır. İyi niyet ise, bir ortağın diğerine karşı iyi duygu ve düşüncelerle yaklaşması, onun çıkarlarını gözetmesi olarak tanımlamamız mümkündür [23].

Güven, organizasyonlar, gruplar ve insanlar arası ilişkilerin devamlılığında en göze çarpan faktör olarak karşımıza çıkmaktadır. Güven; iletişim ve bilginin en doğru șekilde iletilmesi, problemlerin çözülmesi, yetki verilebilmesi ve amaç ve sorumlulukların paylașilması gibi, ortaklar arası birçok ilişkiyi etkileyen bir değişkendir. Yüksek dereceli güven duygusu, düşük dereceliye oranla daha fazla sadakati ve bağlılığı beraberinde getirmektedir [24]. Karşllılı güven duygusunun sağlanmış olması, üyeler arasındaki ilişkinin geliştirilmesi ve uzun süreli devamının sağlanması açısından önemlidir [25].

Kanal üyeleri arasında güven duygusunun olması işbirliğini pozitif yönde etkileyecektir. Çünku, firmanın sormasına gerek kalmadan ortağın bilgi ve firsatlar 
konusunda kendisine bilgi vermesi, uygun amaç ve niyetlerin daha iyi bir şekilde iletilmesi, iletişimin açık bir şekilde sürdürülmesi ve müşteri ihtiyaçlarının tam zamanında cevap verilebilmesi, ancak ticari ortak ile aralarında iyi bir ticari ahlakın, doğruluğun, dürüstlügüün ve dolayısıyla karşlıklı güven duygusunun olmasına bağlıdır. Yapılan çalışmalar kanal üyelerinin ortaklarına güven duymalarının, daha iyi, açı bir iletişime ve firsatların yakalanmasına yardım ettiğini ortaya koymuştur [23]. Güven aynı zamanda, çatıșmaları azaltır ve kanal üyelerinin memnuniyetini artırır [26].

\section{HIIPOTEZLER}

Şekil.1'de, bayilerin ana /tedarikçi firmaya karşı işbirliği davranışlarım etkileyen iki temel faktör (bağımlılık ve güven) şematik olarak ortaya konmaktadır. Bayilerin ana firmaya karșı bağımlılıkları, ana firmaların bayilere olan bağımlılıkları ve bayilerin glivenini içeren bu modeldeki hipotezler aşağıda tartışılmaktadır.

Bağımlllık: Bayinin ana firmaya karşı bağımlılık derecesinin yüksek olması, yani üretici ya da tedarikçinin daha güçlü bir pozisyonda bulunması, bayinin genelde işbirliği içerisinde çalışmasını zorunlu kılmaktadır. Bağıml durumdaki bayii için geleceğini güvence altına alma açısından işbirlikçi davranış sergilemesi önemlidir ve bu sebeple bayii bağımlılığı işbirliği davranışını pozitif yönde etkileyen bir değişken olarak karşımıza çıkmaktadır. Anderson ve Narus [27], Heide ve John [9], Ganesan [28], Lusch ve Brown [25], Anderson, Lodish ve Weitz [29] gibi araştırmacılar bağımlılık üzerine araştırmalar yapmışlar ve bağımlılık değişkeninin işbirliği üzerinde pozitif bir etkiye sahip olduğunu belirtmişlerdir. ilişki vardır.

H1: Bayi bağımlılığı ile güven arasında pozitif bir

H2: Bayi bağımlılı̆̆ ile bilgi paylaşımı arasında pozitif bir ilişki vardır.

H3: Bayi bağımlılığı ile esneklik arasında pozitif bir ilişki vardır.

H4: Bayi bağımlılı̆ı ile birlik anlayışı arasında pozitif bir ilişki vardır.

H5: Ana firmanın bağımlılı̆̆ı ile gäven arasında pozitif bir ilişki vardır.

H6: Ana fürmanın bağımlılı̆̆ı ile bilgi paylaşımı arasında pozitif bir ilișki vardır.

H7: Ana firmanın bağımlılığı ile esneklik arasında pozitif bir ilişki vardır.

H8: Ana firmanın bağımlılı̆̆ı ile birlik anlayışı arasinda pozitif bir ilișki vardır.
Güven: İşbirliği, geçen zaman süresi içerisinde beklenen karşıllkli amaçlara ulaşmak için bağımsız ilişkiler içerisinde tamamlayıcı veya benzer eylemlerin firmalar tarafindan üstlenilmesidir. Bu sebeple, ortaklar arasında güvene dayalı bir ilişki kurulması .ilişkinin devamının sağlanabilmesi ve taraftarın işbirlikçi davranış sergilemeleri açısından büyưk önem sağlamaktadır. Anderson ve Narus'a [30] göre öncelikle ortaklar arasında güven ortamı kurulmakta, işbirliğinin pozitif etkileri ancak daha sonra ortaya çkmaktadır. Ayrıca birçok araştırmacı da yaptıkları çalışmada işbirliği ile güven arasında pozitif bir ilişki olduğunu ortaya koymuşlardır $[21,28,31]$.

H9 : Bayiinin güveni ile bilgi paylaşımı arasında pozitif bir ilişki vardır.

H 10: Bayiinin güveni ile esneklik arasında pozitif bir ilişki vardır.

H 11: Bayiinin güveni ile birlik anlayışı arasında pozitif bir ilişki vardır.

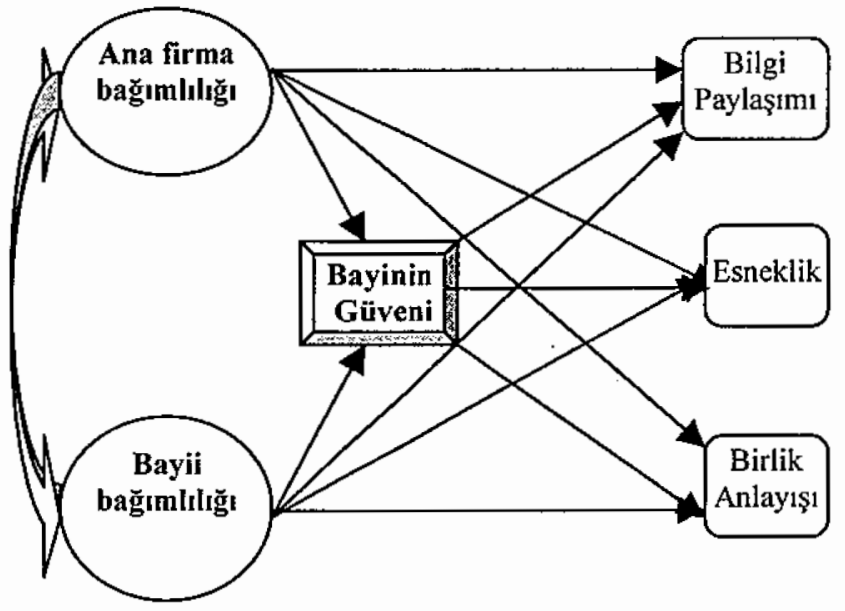

Şekil.1: $\quad$ Yapısal Modelin Şematik İfadesi

\section{UYGULAMA}

\section{A. Veri Toplama}

Niteliği itibarıyla araștırmamı, bayilik sisteminden oluşan dağıtım kanallarında bayilerin işbirliği davranışlarını konu alan tanımlayıcı (betimsel) bir araştırmadır. Araştırma sonuçlarının içsel geçerliliğinin güçlendirilmesi amaciyla tek bir sektöre odaklamanın ve verilerin bu sektördeki bayilerden toplanmasının faydalı olacağına karar verilmiștir. Bu sebeple araștırma verileri, Türkiye'de faaliyet göstermekte olan binek otomobili sektöründeki firmaların bayilerinden anket yöntemiyle ve posta yoluyla toplanmıştır. Öncelikle, gerek Internet yoluyla gerekse ilgili firmalara ulaşmak suretiyle, Tïtkiye 
coğrafyasında faaliyet gösteren ve üretici fïrmalardan bağımsız çalışan bütün otomobil bayilerinin (yaklaşık 1000 adet) adreslerine ulaşılmış ve bunların tamamına içerisinde geri dönüş için pullu ve adresli bir zarfinda yer aldığı anket formu gönderilmiștir. Tüm bu uğraşlar sonucunda 192 adet anket elimize ulaşmıştır. \%20'ye yakın bir geri dönüş oranı sağlanmıştır ve bu oran uluslararası yayınlarda benzer çalışmalara bakıldığında normal bir geri dönüş oranı olarak kabul edilmektedir.

\section{B. Değişkenlerin Ölçümü}

Otomotiv sektöründe bayilerin üretici firmaları ile olan işbirliği davranışlarının nasıl olduğunu ölçmek için öncelikle literatürdeki konu ile ilgili yapılan çalışmalar ayrıntılı olarak incelenmiştir. Ölçmeyi düşündügümüzz değişkenlerle ilgili mevcut ölçekler arasından en iyileri amaca yönelik olarak seçilmiştir. Anket formundaki sorular oluşturulurken, ülkemizin ve Türk otomotiv sektörünün özellikleri de göz önünde bulundurulmuş ve her bir soru İstanbul'da faaliyet gösteren beş ayrı bayi yöneticisi ile yapılan karşıltklı görüşmeler ile ön teste tabi tutulmuştur. İşbirliği davranışlarını oluşturan bilgi paylaşımı, esneklik ve birlik anlayışı soruları Lusch ve Brown [5]'dan, güven soruları Morgan ve Hunt [21] ve Yılmaz [32]'dan, bayi ve ana firma bağımlılığı ile ilgili sorular ise, Ganesan [28], Heide ve John [9], Lusch ve Brown [5] ve Yilmaz [32]'dan adapte edilerek anket formu titiz bir çalışma sonucunda oluşturulmuştur.

\section{Analiz ve Sonuçlar}

Hipotezlerimizin testlerine ve sonuçlarının değerlendirilmesine geçmeden önce, modelimizde kullandı̆̆ımız yapısal kavramların ölçüm geçerlilik ve güvenilirliklerinin değerlendirilmesi ve ilgili psikometrik özelliklerinin ortaya çkarılması gereklidir. Geliştirdiğimiz yapısal kavramlar arası bağlantıları içeren hipotezlerin test edilmesi için, kullandığımız ölçek tekniklerinin genel kabul görmüş kriterler çerçevesinde "yeterli" olduklarının daha önceden gösterilmesi gerekmektedir. Bu amaçla, - araştırmamız sürecinde elde ettiğimiz verilerin analizi için "yapısal denklemler modellemesi" (structural equations modeling) tekniğinden yararlanilacak ve Anderson ve Gerbing [33] tarafindan önerilen iki-aşamalı yaklaşım kullanılacaktır. Bu yaklaşımın birinci aşamasında, ölçüm ilişkilerinin (kavram geçerliklerinin) yapıssı bir dizi "doğrulayıcı" (confirmatory) faktör analizi sonucu ortaya çıarılmaktadır. İkinci aşamada ise mümkün olan en iyi ölçüm modeli geliştirildikten sonra yapisal hipotezlerin irdelenmesine geçilmektedir.
Arașturmamızda odak oluşturan bağımlılık kavramı, aslında (1) karşı furmanın yerine konulabilirìği, (2) karşı firmadan elde edilen ekonomik değerin önemi ve ikame edilebilirliği ve (3) karşı firmayla iş ilişkisine özgün olarak gerçekleştirilen toplam yatırımların değeri olmak üzere ụ̧̈ alt-bileşen tarafindan oluşmaktadır. Anketimizde bayilerin bağımlılı̆̆ı toplam 13 soru ile ölçülmüștür. Söz konusu 13 soru içinde, yerine konulabilirlik ve özgün yatırımlar 4'er soru ile, ekonomik önem ise 5 soru ile ölçülmüş̧ür. Aynt şekilde, bayilerin üretici firmaların kendilerine olan bağımlılı̆ı ile ilgili algıları ise 10 soru ile ölçülmüştür. $\mathrm{Bu}$ sorular bayi bağımlılığı ölçeğinde kullanılan 13 soru ile paralel ifadeler içermektedir; özgün yatırımlar ve ekonomik önem 3'er soruyla, yerine konulabilirlik ise 4 soruyla ölçülmüștür.

Her iki yapısal kavram için iki-seviyeli doğrulayıcı faktör analizi modelleri oluşturulmuş ve LISREL 8.3 programında kovaryans matrisi girdi olarak kullanılarak analize tabi tutulmuştur. Bu tür modellerin birinci seviyesi anket soruları ile alt-bileşenler arasında varlığı iddia edilen ilişkileri içermekte, ikinci seviyede ise üç altbileşenin bir araya gelerek genel "bağımlılık" faktörünu oluşturduğu modellenmektedir. Her iki doğrulayıcı faktör analizi sonucunda iki-aşamalı bağtmlılık ölçüm modelinin veriler ile uyumlu olduğu gözlemlenmiştir. Beklendiği gibi, $\chi^{2}$ istatistikleri 0,05 seviyesinde modelin öngördüğü kovaryans matrisi ile gözlemlenen kovaryans matrisi arasında anlamlı bir fark olmadığına işaret etmekte ve uyum indisleri bu bulguları desteklemektedir (örneğin, CFI $>0,90 ;$ GFI $>0,90 ;$ RMR $<0,05$ ). Aynı zamanda, bütün elemanlar (sorular) ilgili faktörlere istatiksel olarak anlamlı ve 0,50 'den büyük standart katsayılarla yüklenmekte ve yapılan ek analizler faktörler arası korelasyonların birden küçük olduğunu gōstermektedir. $\mathrm{Bu}$ şekilde, farklı soruların aynı faktörü uyumlu bir şekilde ölçtükleri (convergent validity) ve bağımlılığın üç alt-bileşeninin anlamlı bir şekilde ayrıştı̆̆ı (discriminant validity) ortaya konmuş olmaktadır.

Ölçüm analizlerinin ikinci aşamasinda, her iki bağımlılık faktörünü oluşturan alt-bileşenlerin her biri kendi içinde birleştirilerek (soruların aritmetik ortalaması alınarak) kompozit değişkenler oluşturulmuş ve bu değişkenler genel ölçüm modelinde bağımlılık faktörlerinin elemanları olarak kullanılmıştır. Bu modelde ayrıca, bayinin üreticiye karşı duyduğu güven faktörü (8 soru -eleman-) ve işbirliği davranışlarını oluşturan (1) bilgi paylaşımı (4 soru -eleman-), (2) esneklik (3 soru -eleman+) ve (3) birlik anlayışı (4 soru eleman) faktörleri bulunmaktadır. Başka bir deyişle, model 24 gözlemlenmiş değişken ve bunlar ilintilendirilen 6 faktörden oluşmaktadır. Farklı türdeki işbirliği davranışlarının güiven ve bağımlılık faktörlerinden farklı şekilde etkilenebilecekleri ve hipotez testleri sonucunda elde edilebilecek bu tür bulguların gerek teorik gerekse yönetim uygulamaları açısından önemli bilgiler 
içerebileceği öngörüldüğünden, işbirliği faktörünün genel bir yapısal kavram olarak incelenmesi yerine her üç farklı boyutunun ayrı ele alınması uygun görülimüştür. Bu model esas alınarak uygulanan dogrtulayıcı faktör analizi modeldeki ölçüm ilişkilerinin veri ile uyumlu olduğunu açıkça işaret etmektedir $\left(\chi_{\text {(serbestlik derecesi }=237)}^{2}=471,6 ; \mathrm{CFI}\right.$ $=0,94 ;$ GFI $=0,92 ;$ RMR $=0,051)$. Ayrica, bir önceki analizde olduğu gibi, bütün elemanlar (sorular) ilgili faktörlere istatiksel olarak anlamlı ve 0,50 'den büyük standart katsayılarla yüklenmekte ve yapılan ek analizler faktörler arası korelasyonların birden küçûk olduğunu göstermektedir. Modeldeki faktörler arası korelasyonlar, tanımlayıcı istatistikler ve faktörlerin ölçümü için kullanılan ölçeklerin (soru demetlerinin) alfa güvenilirlik katsayıları Tablo 1 de verilmektedir. Ölçüm ilişkileri bu şekilde netleştirildikten sonra Şekil.1 de şematik biçimde ifadesini bulan yapısal modelin ve araştirma hipotezlerinin testine geçilmiştir.

Tablo.1: Değişkenlere Ait Ortalama, Standart Sapma, Alfa Katsayıları ve Korelasyonlar

\begin{tabular}{lllllllll}
\hline Ort.* & Std. & & Bdep & Guv & Info & Flex & Sol & Adep \\
\hline 5,3997 &, 0356 & Bdep & $.77^{* *}$ & & & & & \\
4,8746 &, 5938 & Guv & .41 & .92 & & & & \\
6,1797 &, 0364 & Info & .42 & .30 & .85 & & & \\
5,3042 &, 2762 & Flex & .48 & .23 & .71 & .71 & & \\
6,0734 &, 9975 & Sol & .47 & .25 & .71 & .71 & .86 & \\
4,6013 &, 1025 & Adep & .52 & .37 & .19 & .37 & .23 & .78 \\
\hline
\end{tabular}

* Túm değişkenler l'den 7'ye kadar olan ölçek ile ölçülmüştür.

** Alfa gìvenilirlik katsayıları

(Ort: Ortalama, Std: Standart sapma, Bdep: Bayi bağımlılı̆̆, Guv: Güven, Info: Bilgi paylașımı, Flex: Esneklik, Sol: Birlik anlayışı ve Adep: Ana firma bağımlılığ

Yapısal modeli oluşturan hipotezlerin testi için de LISREL 8.3 programı kullanımıştır. Genelde yapısal modeller ölçüm modeline göre daha fazla kısıt içermekle birlikte (daha fazla parametrenin sıfira eşit kılınarak kısıtlanan modeller), araştırmamızda kullanılan yapısal model bütün faktörler arasında bağıntılar önerdiği için bir önceki ölçüm modeli ile aynı parametrik özelliklere sahip bulunmaktadır. Dolayısıyla, yapisal modelin eldeki veriye uyumu ölçüm modeli ile ayni istatiksel özellere sahiptir. $\mathrm{Bu}$ modelle asıl gerçekleştirilmek istenen bağımlılık, güven ve işbirliği faktörleri arasında varlığı iddia edilen istatiksel bağıntıların test edilmesidir. Nitekim, analiz sonuçlarına göre modelde var olan 11 bağıntının 6'sı istatiksel olarak anlamlı bulunmuştur.
Tablo.2: Sonuçların Özeti

\begin{tabular}{|c|c|c|}
\hline İlișkiler & Katsayılar & t-değerleri \\
\hline Güven $\rightarrow$ Bilgi Paylaşımı & 0.17 & $1.86^{*}$ \\
\hline Güven $\rightarrow$ Esneklik & 0.01 & 0.12 \\
\hline Güven $\rightarrow$ Birlik Anlayışı & 0.08 & 0.91 \\
\hline Bayi Bağımilılı̆̆ $\rightarrow$ Güven & 0.30 & $2.45^{* *}$ \\
\hline $\begin{array}{l}\text { Bayi Bağımlılığı } \rightarrow \text { Bilgi } \\
\text { Paylaşımı }\end{array}$ & 0.38 & $2.74^{* *}$ \\
\hline Bayi Bağımlılığ $\rightarrow$ Esneklik & 0.38 & $2.59 * *$ \\
\hline $\begin{array}{l}\text { Bayi Bağımlılı̆̆ı } \rightarrow \text { Birlik } \\
\text { Anlayışı }\end{array}$ & 0.45 & $3.18^{* *}$ \\
\hline $\begin{array}{l}\text { Ana Firma Bağımlılığı } \rightarrow \\
\text { Güven }\end{array}$ & 0.22 & $1.94^{*}$ \\
\hline $\begin{array}{l}\text { Ana Firma Bağımlılığı } \rightarrow \\
\text { Bilgi Paylaşımı }\end{array}$ & -0.07 & -0.62 \\
\hline $\begin{array}{l}\text { Ana Firma . Bağımlılı̆̆ı } \rightarrow \\
\text { Esneklik }\end{array}$ & 0.17 & 1.32 \\
\hline $\begin{array}{l}\text { Ana Firma Bağımlılığı } \rightarrow \\
\text { Birlik Anlayıșı }\end{array}$ & -0.03 & -0.31 \\
\hline
\end{tabular}

$\chi_{(237)}^{2}=471.6$, CFI (Comparative Fit Index $)=0.94$, GFI(Goodness of Fit Index) $=0.92$, RMR (Root Mean Square Residual) $=0.051$

$$
\begin{aligned}
& { }^{*} \mathrm{p}<.05 \text { (tek tarafl1 testler) } \\
& { }^{*} \mathrm{p}<.01
\end{aligned}
$$

Tablo.2'de de özet olarak gösterildiği gibi, bayilerin üretici firmaya karşı bağımlılık seviyeleri, üretici firmaya karşı (1) geliştirdikleri güven düzeyini $(\gamma=$ $0,30 ; \mathrm{p}<0,05)$, (2) bilgi paylaşımı seviyelerini $(\gamma=0,38$; $\mathrm{p}<0,01)$, (3) esneklik eğilimlerini $(\gamma=0,38$; $\mathrm{p}<0,01)$ ve (4) birlik anlayışını $(\gamma=0,45 ; p<0,01)$ olumlu (pozitif) ve istatiksel olarak anlaml şekilde etkilemektedir. Bayilerin üretici firmanın bağımlılığı yönündeki algıları ise yalnızca üretici firmaya karşı duyulan güven ile bağıntılı bulunmuș $(\gamma=0,22 ; p<0,05)$, işbirliği davranıșı türlerinin hiçbiri ile bağıntılı bulunmamıştır (bütün katsayılar için, $p>0,05$ ). Son olarak, uretici firmaya duyulan güven bilgi paylaşımını olumlu etkilemekte $(\beta=$ 0,$17 ; p<0,05$ ), ancak esneklik ve birlik anlayışı üzerinde ciddi bir etkide bulunmamaktadır (her iki katsayı için de $\mathrm{p}$ $>0,05$ ). Bu bulgulara göre, üretici firmanın bağımlılık seviyesi ile ilgili bayi algıları işbirliği davranışlarından sadece bilgi paylaşımını dolaylı olarak (üreticiye duyula güveni artırarak) etkileyebilmektedir. Bayilerin kendi bağımlılık seviyeleri ile ilgili düşünceleri ise, gerek güven seviyelerini gerekse her türlư işbirliği eğilimlerini direkt olarak etkileyen önemli faktörlerden biri olarak ortaya çıkmaktadır. 
Sonuç olarak, araștırmamıda kullanılan öncül faktörler, güven seviyesindeki toplam varyansin $\% 20^{\prime} \operatorname{sini}$, bilgi paylaşımının $\% 20$ 'sini, esnekliğin $\% 25$ 'ini ve birlik anlayışımın \%22'sini açıklamaktadır. Bu oranlar, genel olarak tatmin edici rakamlardır ve benzer çalışmalara bakıldığında oldukça yüksektir.

\section{SONUÇ}

Araştırmamız bayi işbirliği gibi önemli bir konuyu araştırmakta, bunu yaparken Türk otomobil sektörü gibi ekonominin lokomotifi olarak kabul edilen son derece önemli bir sektörü irdelemektedir. Yoğun bir rekabetin yaşandığı otomotiv sektöründe bayilik sistemi yaygın olarak kullanıımaktadır ve firmaların başarısında bayileri ile olan ilişkilerinin büyük rolü bulunmaktadır. Bu sebeple, üretici ya da tedarikçi firmalar rakipleri karşısında daha başarılı bir performans sergilemek istiyorlarsa, bayilerinin onlara karşı işbirliğine yönelik davranışlar sergilemesine yeterli önemi vermeleri gerekmektedir. Çünkü taraflar arasında etkin bir işbirliğinin geliştirilmesi ile her iki tarafinda karlı çıktığı bir kanal sistemi ortaya çıkmaktadır. Ayrıca işbirliği içerisindeki firmalar birbirleri ile bilgi ve tecrübelerini diğerlerine oranla daha verimli bir şekilde paylaşır, aralarındaki işbölümünü daha etkin bir şekilde gerçekleştirir ve birbirlerini daha iyi anlar ve yardımcı olurlar.

Teorik olarak, literatür ve diğer araştırmalar genelde ya bağımlılık faktörünü (power dependence paradigması) ya da uzun dönemli ilișki ve gâven faktörünü ele almışlardır (relationship marketing paradigması). Araştırmamız bu iki temel faktörün birlikte etkilerini araşttran ender örneklerden biridir. Taraflar arasında karşılıklı bağımlılık derecesinin simetrik ya da asimetrik olmasının ve güven gibi iliş̧kisel faktörlerin işbirliği üzerinde oldukça önemli bir etkiye sahip olduğu yadsınamaz bir gerçektir. Ancak tek başına bağımlılıkgụ̈ ya da güven kavramı taraflar arasındaki iliş̧iyi anlamada yetersiz kalacaktır. Taraflar arasında karşilıkh bağımllı̆̆ın ve güven duygusunun mevcudiyeti, dağıtım kanalının verimli ve etkin bir şekilde işlemesinde oldukça önemli unsurlardır. Her iki taraf ta birbirine bağımiı durumda ise uzun dönemli olarak ilișkinin devamlılığı sağlanabilmekte ve ayrica güven duygusu ile de bu durum perçinlenmektedir. Kısaca, kanal ortaklarının karşılıklı amaçlarına ulaşmalarında oldukça önemli olan işbirliğini ele alırken, hem güç-bağımlılık hem de ilişkisel faktör olan güvenin beraberce degerlendirilmesi gerekmektedir. Araştırmamızin sonuçları da gőstermektedir ki bu faktörler birbirleri ile yakın iliş̧i içerisindedir.

Sonuçlar bayi ilişkileri yönetimini ve genel olarak bayilik sistemini kullanan otomobil firmaları için önemli bilgileri gün ışı̆ıına çıkartmaktadır. $\mathrm{Bu}$ bulgular sonucunda ortaya çıkan önemli sonuçları genel olarak iki genel başlik altında özetlememiz mümkündür.

- Üretici firmalar bağımlılık ilişkileri yönetimine büyük önem vermek durumundadırlar. Özellikle güven derecesi ve üreticilerin kendi bağımlılığı değişmezken (sabitken), bayilerin bağımlılığında meydana getirilen artı̧lar yalnızca güven seviyesini artırmakla kalmamakta, aynı zamanda işbirliğinin her türlüsünü direkt olarak etkilemekte, bayileri işbirliğine yönlendirmektedir. Yani bayilerin çeşitli sebeplerden dolayı bağımlılık dereceleri (özgün yatırımların miktarındaki artış yoluyla, üreticinin yerine geçebilecek alternatiflerin azlığı nedeniyle ve/veya üretici öneminin bayi için oldukça yüksek olması gibi nedenlerle) artırılırsa, bayilerin güven seviyeleri ve işbirliğine yönelik davranışlarında (bilgi paylaşımı, esneklik ve birlik anlayışı) artışlar olacaktır. Bayileri gönüllü olarak yüksek işbirliği gösteren firmaların uzun dönemde daha başarılı olacağı açıktır.

- Üretici firmanın bağımlılık seviyesindeki artı̧lar ise işbirligini direkt olarak etkilemekle birlikte, bayilerin üreticiye olan güvenini arturmaktadır,Yani üreticinin bağımlılık seviyesinin yüksek olması, bayi için ona karşı olan güven duygularının gelişmesine yardımcı olmakta ve güveninin doğal bir sonucu olarak ta bilgi paylaşımı seviyesinde artı̧̧lar görülmektedir. Bayilerin güven duygusundaki artşlar doğaldır ki, üretici ile kritik, önemli ve özel bilgileri zamanında ve doğru bir şekilde paylaşımı sonucunu ortaya çıartacaktır. Bu bilgiler üreticiler açısından hayati önem taşımaktadır ve bunların bayi tarafindan kendilerini aktarılmasındaki gönüllülük oldukça önemli bir husustur. Kendisi için gerekli ve önemli bilgiyi, bayilerinden zamanında ve doğru bir şekilde edinebilen üretici, rakipleri karşısında daha avantajlı durumda olacaktır.

\section{YARARLANILAN KAYNAKLAR}

[1] GILL, E., L.; ALLERHEILIGEN R.P., "Co-Operation In Channels Of Distribution. Physical Distribution Leads The Way", International Journal Of Physical Distribution \&Logistics Management, Vol.26, 1996, ss.49-63.

[2] RING, P.S.; Van De VEN, A. H., "Developmental Processes of Cooperative Interorganizational Relationships," Academy Of Management Review, 19, 1994, ss.90-I 18.

[3] CANNON, Joseph P.; PERREAUlT, Jr. William D., "Buyer-Seller Relationships In Business Markets," Journal of Marketing Research, Vol. 36, November 1999, ss.439-460.

[4] COMBS, J.G.; KETCHEN, J., "Explaining Interfirm Cooperation And Performance: Toward A Reconciliation Of Predictions From The Resource-Based View And 
Organizational Economics", Strategic Management Journal, Vol. 20, 1999, ss.867-888.

[5] LUSCH, L.R.; BROWN, R.J., "Interdependency, Contracting, And Relational Behavior In Marketing Channels", Journal of Marketing, Vol.60, October 1996, ss.19-38.

[6] HEIDE, Jan B.; JOHN, George, "Do Norms Matter In Marketing Relationships?", Journal of Marketing, Vol. 56, April 1992, ss.32-44.

[7] MACNEIL, I., The New Social Contract, Yale University Press, New Haven, 1980.

[8] JAP ,S. D.; GANESAN, S., "Control Mechanisms And The Relationship Life Cycle: Implications For Safeguarding Specific Investments And Developing Commitment," Journal of Marketing Research, 37 May 2000, ss.227-245.

[9] HEIDE, Jan B.; JOHN, George, "The Role Of Dependence Balancing In Safeguarding Transaction Specific Assets In Conventional Channels," Journal of Marketing, Vol . 52, January 1998, ss.20-35.

[10] MORH, J.; SPEKMAN, R., "Characteristics of Partnership Success: Partnership Attributes, Communication Behavior, And Conflict Resolution Techniques", Strategic Management Journal, Vol.15, 1994, ss.135-52.

[11] KUMAR, N.; SCHEER, L.; STEENKAMP, E.M., "The Effects Of Supplier Faimess On Vulnerable Resellers", Journal of Marketing Research, Vol.32, February 1995, ss.54-65

[12] El-ANSARY, A.; STERN, L.W., "Power Measurement In The Distribution Channel," Journal of Marketing Research, 20, May 1972, ss.158-66.

[13] EMERSON, Richard M., "Power-Dependence Relations," American Sociological Reviews, Vol. 27, February 1962, ss. 31-41.

[14] PREFFER, J.; SALANCIK, G.R., The External Control Of Organizations: A Resource Dependence Approach, Harper And Row Publishers Inc., New York, 1978

[15] HALLEN, L.; JAN, J.; NAZEEM, S., "Interfirm Adaptation In Business Relationships" Journal of Marketing, 55, 1991, 5s.29-37.

[16] GUNDLACH, G.T.; CADOTTE, E.R., "Exchange Interdependence And Interfirm Interaction: Research In A Simulated Channel Setting," Journal of Marketing, 52, January 1994, ss.20-35.

[17] LAWLER, E.J.; BACHARACH, S.B., "Comparison of Dependence And Punitive Forms Of Power," Social Forces, Vol. 66, Issue 2, 1987, ss.446-462.

[18] ANDERSON, Erin; WEITZ, Barton A., "Determinants Of Continuity In Conventional Industrial Channel Dyads," Marketing Science, Vol. 8, Fall 1989, ss.310-323.

[19] ANDERSON, E.; WEITZ, B., "The Use Of Pledges To Build And Sustain Commitment In Distribution
Channels", Journal of Marketing Research, Vol.29, February 1992, ss.18-34

[20] HEIDE, Jan B., "Interorganizational Governance In Marketing Channels," Journal of Marketing, Vol. 58, January 1994, ss.71-85.

[21] MORGAN, R.; HUNT, S., "The Commitment-Trust Theory Of Relationship Marketing", Journal of Marketing, Vol.58, July 1994, ss.20-38.

[22] FRAIZER, Gary L., "Organizing And Managing Channels Of Distribution," Journal Of The Academy Of Marketing Science, Vol. 27, Spring 1999, ss.226-240.

[23] SIGUAW, A.J.; SIMPSON, M.J.; BAKERr, L.T., "Effects Of Supplier Market Orientation On Distributor Market Orientation And The Channel Relationship: The Distributor Perspective", Journal of Marketing, Vol.62, 1998, ss.99-111.

[24] GUNDLACK, G.T.; MURPY, P.E., "Ethical And Legal Foundations of Relational Marketing Exchange," Journal of Marketing, 57, October 1993, ss.35-46.

[25] MOORMAN, C.; DESHPANDE, R.; ZALTMAN, G., "Factors Affecting Trust In Market Research Relationship", Journal of Marketing, Vol.57, January 1993, ss.81-101.

[26] DONEY, M.P.; CANNON, P. J., "An Examination Of The Nature Of Trust In Buyer-Seller Relationships", Journal of Marketing, Vol.61, 1997, ss.35-51.

[27] ANDERSON, Erin; NARUS, James A., "A Model Of The Distributor's Perspective of Distributor-Manufacturer Working Relationships," Journal of Marketing, Vol. 48, Fall 1984, ss.62-74.

[28] GANESAN, S., "Determinants Of Long-Term Orientation In Buyer-Seller Relationships", Journal of Marketing, Vol.58, April 1994, ss.1-8.

[29] ANDERSON, E.; LODISH, L.; WEITZ, B., "Resource Allocation Behavior In Conventional Channels," Journal of Marketing Research, 24, February 1987, ss.85-97.

[30] ANDERSON, J.C.; NARUS, J.A., "A Model Of Distributor Firm And Manufacturer Firm Working Partnerships", Journal of Marketing, Vol.54, January 1990, ss.42-58.

[31] ANDALEEB, S.S., "Dependence Relations And The Moderating Role of Trust: Implications For Behavioral Intentions In Marketing Channels", International Journal of Research In Marketing, 12(2), 1995, ss.157172.

[32] YILMAZ, Cengiz, "Salesforce Cooperation: The Impact Of Relational, Task, Organizational, And Personal Factors", Dissertation Thesis, Texas Tech University, 1999.

[33] ANDERSON, J.C.; GERBING, D.W., "Structural Equation Modeling In Practice: A Review And Recommended Two-Step Approach." Psychological Bulletin, 103 (3), 1988, ss.411-23. 